\title{
Implementing Mixed Method of Peer Teaching and Problem Solving on Undergraduate Students
}

\author{
A. Firli 1, *, R. Rismayani ${ }^{2}$, P.M.T. Sitorus ${ }^{3}$, B. Manuel 4 \\ ${ }^{1}$ Department of Magister Management, Telkom University, Indonesia \\ 2 Department of Magister Management, Telkom University, Indonesia \\ ${ }^{3}$ Department of Magister Management, Telkom University, Indonesia \\ ${ }^{4}$ Department of Telecommunication and Informatics Business Management, Telkom University, Indonesia
}

\begin{abstract}
This study examined the application of problem solving method combined with student centered learning (peer teaching) method as a mixed method to improve student's passing level of financial management course. The object of this study was the 84 students of financial management course separated within two classes during the odd semester period 2014/2015, July until December 2015 with fourteen meeting courses. Data used to measure the results of the application is mid and final exam scores of both classes. Researcher used observation, interview and documentation as data collect technique also triangulation technique as data validity check. This study used problem solving method combined with student centered learning (peer teaching) method as a mixed method which included into the Classroom Action Research. The final results show the increase in class A passing level is $17 \%$. Class B passing level increased 3\%. From the research we also know that in practical use of mixed method learning, leader's quality and conducive learning environment are influencing factors in improving student's learning performance. While the result confirms that mixed method improving learning performance, this study also founds additional factors that might be considerably affecting the results of learning performance when implementing the mixed method.
\end{abstract}

\author{
Keywords: \\ Classroom Action \\ Research, \\ Mixed method, \\ Peer Teaching, \\ Problem Solving Method
}

\section{Introduction}

Modern teaching has been shifting its focus from teacher-centered learning to student centered learning. Collaborative role between students and teacher critically needed to achieve interactive and innovative learning. The approach is strongly recommended for teaching in Telkom University, but still there are teachers who teach in conventional ways that weighting their students with heavy facts, recitation and boring concepts. Therefore, to induce student-centered learning from those conventional teaching we are in need of an update in teaching methodology.

Financial Management course is one of undergraduate subjects for students in Business Management in Telecommunication \& Informatics major in Telkom University. The course is giving students basic principle in financial management study. Based on researcher's observation, this course currently having high percentage of students failing the course. Data show that the students who failed in this subject is $39.08 \%, 204$ of 544 students. From the observation, we also found the main problems student faced during course, which are: 1) The course is becoming a problem for students without competency in mathematical operation; 2) Prejudice of complex problem within the course inducing fear to students in learning the course; 3) Students found that the learning process are not appealing; 4) Prejudice of next chapter of the course will be much harder that the current chapter even though both of them are unrelated.

From the problems found during the observation, researchers decide that there must be a renewal for the course, either method renewal or increase tshe relevance of teaching methods. Therefore, with this study researcher are implementing problem solving method combined with student centered

\footnotetext{
* Corresponding author.

E-mail Addresses: anisahfirli@telkomuniversity.ac.id (A. Firli), risrisrismayani@telkomuniversity.ac.id (R. Rismayani),

paltisitorus@telkomuniversity.ac.id (P.M.T.Sitorus),bramonoool@students.telkomuniversity.ac.id (B. Manuel)
} 
learning (peer teaching) method as a mixed method to examine whether it will improve student's passing level or not.

\section{Method}

This study use problem solving method combined with student-centered learning (peer teaching) method as a mixed method with Kemmis\& McTaggart's model (Figure 1), these methods included into the Classroom Action Research. Classroom action research has certain characteristic which are: (1) situational; (2) contextual; (3) collaborative; (4) self-evaluative and flexible. In the early stages, the researchers conducted assessments to determine the perceived problems. At this stage, researchers can identify problems in teaching practice, then perform analysis and formulate a problem for action research. In the second stage, based on the selected issues, plans action to make improvements, enhancements and changes for the better of practice learning. In the third phase, conduct the implementation plan with monitoring. Record all events and changes need to be done with a variety of tools according the conditions and situation of the classroom. In the fourth stage, based on results of monitoring, conduct data analysis as reference material to evaluate the objective has been achieved. If not qualified, conduct modification and redesign to improve the actions during the previous cycle. Recycling process will end if the outcome of the action is qualified.

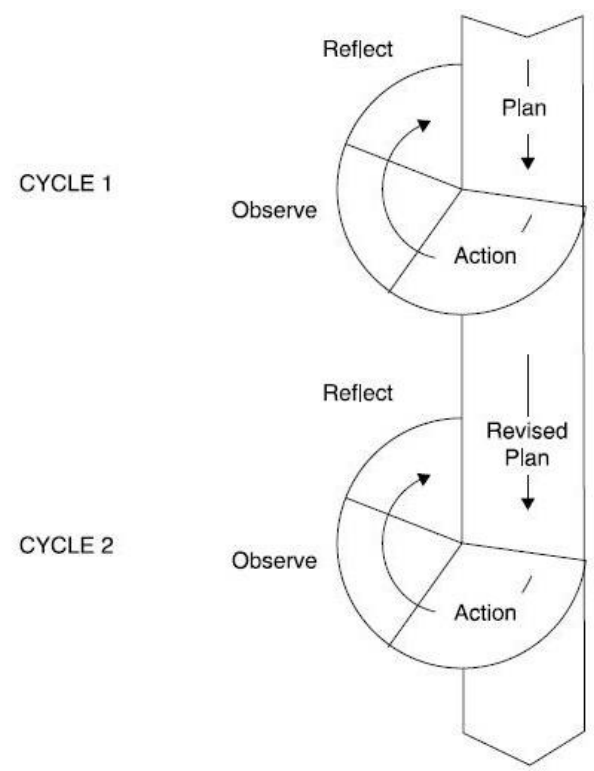

Figure 1. Action Classroom Research Model by Kemmis \& Mc Taggart (1988, pp. 22-25)

From Kemmis\& McTaggart's model, researchers develop two-phase research model (Figure 2). Here is the explanation of the steps: at the planning stage researchers develop guidelines, plans and strategies for learning process and observation. In action stage, researchers analyze the teaching activities from pre-designed Lecture Plans. In observe stage, researchers observe the learning process to find out activities that should be improved and should be maintained in order to achieve the research objectives. The researcher also observes student's active level during the learning process. In reflect stage, researchers conduct a reflection of results found during activities on first cycle, and analyze obstacles and motivation possibly happen in the second cycle. Expected outcome of these interventions is the change in learning strategy used in improving student's comprehension and choose the appropriate method for financial management subject.

The object of classroom action research are students of financial management subject of A Class with 40 students and B Class with 44 students, pre-test data is required at the beginning of the intervention. The study conducted at the lecture odd semester period 2014/2015, July until December 2015 with fourteen meeting course. Data used to measure the results of the application is mid and final exam scores of both classes. Researcher use observation, interview and documentation as data collect technique. Data validity check using triangulation technique (Moeloeng, 2002, p. 178) to meet data credibility, transferability, dependability and confirmability. 
In these study data analysis techniques is a quantitative and qualitative technique. The qualitative analysis is the analysis of the learning process continuously from first course until the end of study. The qualitative analysis provides real interpretation of the activity of student in the learning process using a combination of methods. Observation sheets fill by collaborators about the activity of the teacher and student in the learning process.

Test data in quantitative analysis with the following steps:

1. Calculate the test-score of the respondents from each aspect.

2. Recap the student's scores.

3. Calculate the average students score.

4. Calculate the percentage value.

This percentage is calculated using the following formula:

$\mathrm{PS}=\frac{\mathrm{CS}}{\mathrm{R}} \times 100 \%$

PS: Percentage Score

CS: Cumulative Score

R: Number of Respondents

The results of calculating the students score then compared with the first cycle test results and second cycle test results. These results will provide an overview of the percentage increase/decrease of student comprehension by using a combination of learning methods.

\section{Result and Discussion}

Figure 2 depicts the result found during the $1^{\text {st }}$ cycle of research. The grade of students after evaluation in mid-term exam. $70 \%$ of students in A Class are able to obtain passing score which is equal or more than 60 and $30 \%$ of them are fail to do so. Meanwhile in B Class only $52 \%$ from the students manage to obtain passing score from mid-term exam.

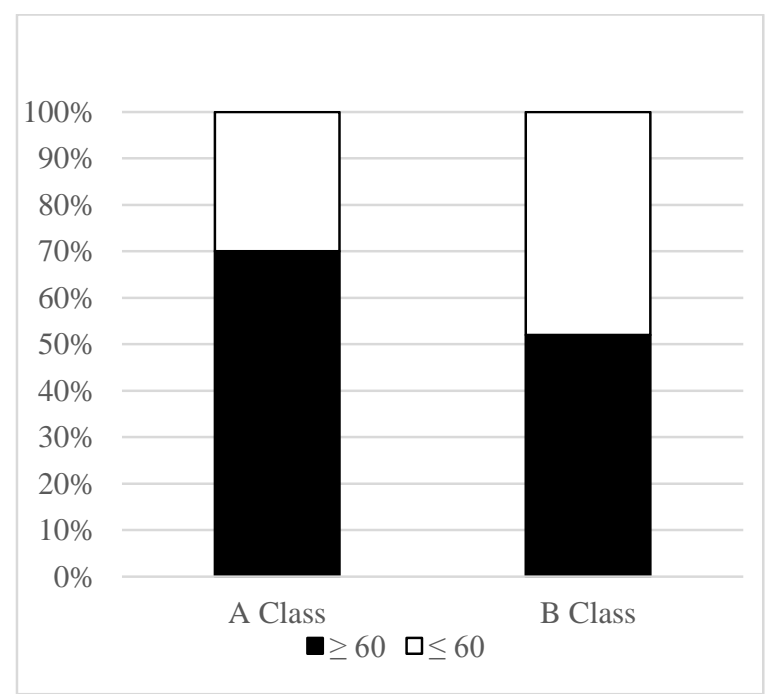

Figure 2: Students Mid-Term Results

Based on reflection conducted in 1st cycle, we found that main problem that interfering the optimal result are leader's capability and learning media. To resolve these problems, there will be improvement in 2nd cycle. Planned improvements are including leader's training, leader's evaluation (which might cause group leaders turnover), and usage of print-out material and problems for students.

Figure 3 shows percentage of students passing the Financial Management subject from pre-test and post-test. Both class start with $61 \%$ students passing the Financial Management subject. After implementing Mixed Method, A-class percentage went up by 17\%, meanwhile in B-class the percentage went up by $3 \%$. The results are showing positive increase in percentage of students passing the Financial Management subject, therefore we can conclude that Mixed Method is able to improve the quality of teaching. 


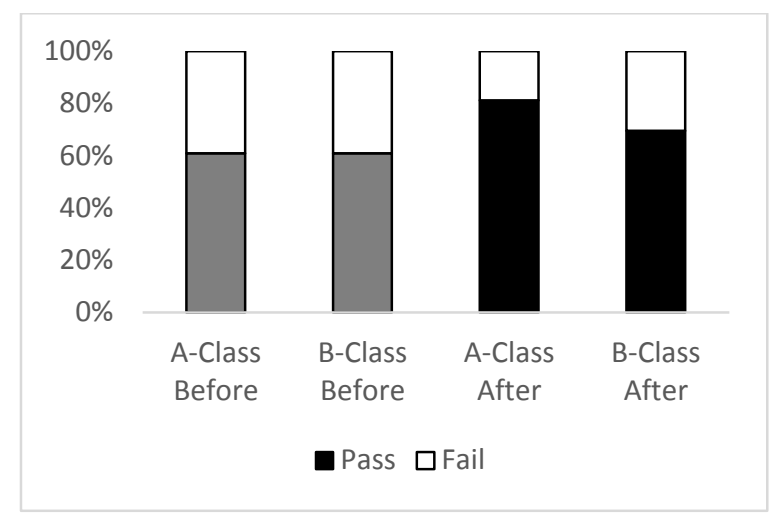

Figure 3: Students Passing Level

From the observation sheets and questionnaire distributed to the students, we know that A-class is having better understanding in class by using Mixed Method. 89\% A-class students agree that by using Mixed Method, the lesson became more interesting and $82 \%$ of them agreed that they could have better discussion. Meanwhile in B-class, only $61 \%$ of the students agreed with the same statements. Qualitative research also showed how the students value the quality of their group leaders. In A-class, approximately $80 \%$ of the students agreed that their leader is having good quality in peer teaching. Meanwhile in B-class, only $64 \%$ students agreed to the same statements.

The results showthat by conducting mixed method can improve learning performance. It is indicated by improvement in student's passing level of the subject. From the research we also know that in practical use of mixed method learning, leader's quality and conducive learning environment are influencing factors in improving student's learning performance. Chou and Liu (2005) supports this finding by their research results which state that different learning environment will results in different learning results.

In previous research by El-Sayed (2013) and Anggorowati (2011), peer teaching method learning are proven to be improving student's learning performance even if the learning environment, student's grade, and learning subjects are different. The result is also the same for problem-solving method. Previous researches conducted by Hwang et al. (2012) and Ismail et al. (2011) found that problem-solving learning method successfully improving student's learning performance. And to complete the relation between the two method of peer teaching and problem solving method to learning performance, this study finds that mixing both of the method in learning activities will also improve student's learning performance

\section{Conclusions}

From the study, we can conclude that implementation of mixed method of peer teaching and problem solving on the research subject is improving student's performance. Based on the students passing level, there were significant improvement of students' rate of passing the financial management subject, $17 \%$ for A Class and 38\% for B Class. There was also improvement of students' ability to listen and comprehend the course material, significantly for A Class.

For better performance of mixed method, we also suggest to pay attention towards leader and groups assignation. Because group leaders are greatly affecting performance of their fellow groupmates. Another factor to be considered is the environment. A conducive learning environment for group studies will also greatly affecting the performance of mixed method learning.

\section{References}

Anggorowati, N. P. 2011. Penerapan Model Pembelajaran Tutor SebayaPada Mata PelajaranSosiologi. Komunitas: International Journal of Indonesian Society and Culture, 3(1). Retrieved from http://journal.unnes.ac.id/artikel_nju/komunitas/2303

Chou, S.-W. and Liu, C.-H. 2005. Learning effectiveness in a Web-based virtual learning environment: a learner control perspective. Journal of Computer Assisted Learning, 21, 65-76. doi:10.1111/j.1365-2729.2005.00114.x 
El-Sayed, S. H. 2013. Effect of peer teaching on the performance of undergraduate nursing students enrolled in nursing administration course. Journal of Nursing Education and Practice, 3(9), 156. doi:10.5430/jnep.v3n9p156

Hwang, G. J., Wu, P. H., \& Chen, C. C. 2012. An online game approach for improving students' learning performance in web-based problem-solving activities. Computers \& Education, 59(4), 1246-1256. doi:10.1016/j.compedu.2012.05.009

Ismail, S., \&Atan, A. 2011. Aplikasipendekatanpenyelesaianmasalahdalampengajaranmatapelajaran TeknikaldanVokasional di FakultiPendidikan UTM. Journal of Educational Psychology and Counseling, 2(1), 113-144. Retrieved from http://core.ac.uk/

Kemmis, Stephen., Robin McTaggart. 1988. (Eds.). The Action Research Planner. Australia: Deakin University Press.

Moeloeng, Lexy J. 2002. MetodologiPenelitianKualitatif. Bandung: PT RemajaRosdakarya.

Soedarsono, FX. 2001. AplikasiPenelitianTindakanKelas. Jakarta: PAU-PPAI Universitas Terbuka. 